\title{
CHANGES IN THE FISCAL STANCE AND THE COMPOSITION OF PUBLIC SPENDING
}

\author{
Juraj Stančík \\ Timo Välilä
}
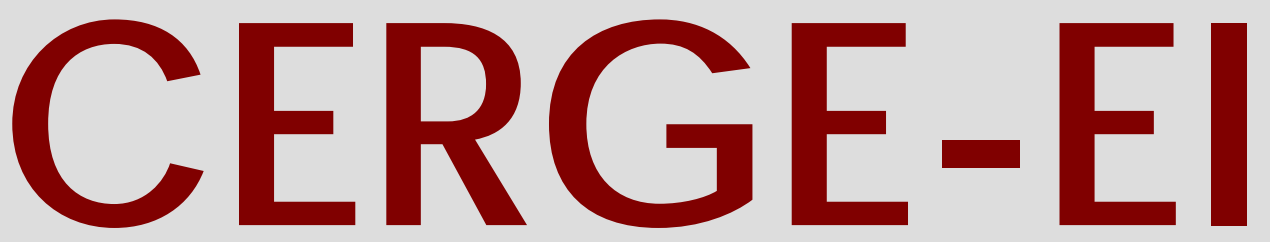

Charles University Centerfor Ec onomic Research and Graduate Education Academy of Sciences of the Czech Republic Ec onomic Institute 


\title{
Working Paper Series (ISSN 1211-3298)
}

\section{Changes in the Fiscal Stance and the Composition of Public Spending}

Juraj Stančík

Timo Välilä

\author{
CERGE-EI \\ Prague, November 2009
}

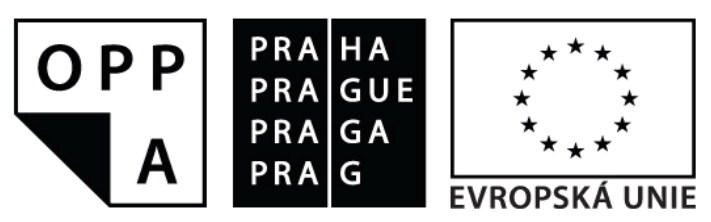

EVROPSKÝ SOCIÁLNÍ FOND

PRAHA \& EU: INVESTUJEME DO VAŠÍ BUDOUCNOSTI

Projekt je financován Evropským sociálním fondem, rozpočtem hl. města Prahy a státním rozpočtem 
ISBN 978-80-7343-196-9 (Univerzita Karlova. Centrum pro ekonomický výzkum a doktorské studium)

ISBN 978-80-7344-185-2 (Národohospodářský ústav AV ČR, v.v.i.) 


\title{
Changes in the Fiscal Stance and the Composition of Public Spending*
}

\author{
Juraj Stanč́́k and Timo Välilä *
}

November 2009

\begin{abstract}
The share of public investment relative to consumption expenditure has declined in past decades. Earlier literature has attributed this stylised fact variably to the relative political ease of cutting investment; different cyclical patterns of public investment and consumption; or to EMU's fiscal rules. We consider the impact of both cyclical and structural changes in the fiscal stance on public spending composition for a panel of EU countries, including individual components of public investment. We find that both cyclically-induced and structural changes in the fiscal stance affect the composition of public spending, with fiscal tightening of both types increasing, not decreasing, the relative share of investment and loosening favouring consumption expenditure. There is, however, some asymmetry in that the gain in investment following a tightening tends to be smaller than the gain in consumption expenditure following a loosening. Of the components of public investment, infrastructure and redistribution respond to cyclical changes in the fiscal stance, while investment in hospitals and schools responds most clearly to structural changes.
\end{abstract}

\begin{abstract}
Abstrakt
Podiel verejných investícií vzhl'adom k výdavkom na spotrebu za posledné desat'ročia klesá. Predchádzajúce štúdie tento fakt často zdôvodňovali politicky l'ahko priechodným škrtaním investícií, rôznymi ekonomickými cyklami pre investície a spotrebu alebo požiadavkami EMU. V tomto článku sa zaoberáme vplyvmi cyklických a štrukturálnych zmien vo fiškálnej politike na verejné výdavky a ich jednotlivé komponenty v krajinách EU. Z výsledkov vyplýva, že cyklické aj štrukturálne zmeny vo fiškálnej politike majú vplyv na zloženie verejných výdavkov - pri oboch zmenách má fiškálne nat’ahovanie pozitívny vplyv na relatívny podiel investící́, zatial čo uvol'ňovanie má presne opačný efekt. Platí tu istá asymetria - nárast pri investíciách $\mathrm{v}$ prvom prípade je menší než nárast spotreby $\mathrm{v}$ druhom. Čo sa týka jednotlivých komponentov, verejné investície do infraštruktúry a prerozdel'ovania reagujú skôr na cyklické zmeny. V prípade investícií do nemocníc a škôl je to naopak.
\end{abstract}

Keywords: fiscal policy, public expenditure, fiscal stance

JEL Codes: E62, H50, H62, C33

\footnotetext{
${ }^{*}$ We would like to thank Evangelia Vourvachaki and Evžen Kočenda for useful comments. We are also grateful to Sarah Peck for editing the manuscript. The views expressed in this paper should not be reported as representing the views of the EIB. The views expressed are those of the authors and do not necessarily represent those of the EIB or EIB policy.

- CERGE-EI is a joint workplace of the Center for Economic Research and Graduate Education, Charles University, and the Economics Institute of Academy of Sciences of the Czech Republic.

Address: CERGE-EI, P.O. Box 882, Politických vězňů 7, Prague 1, 111 21, Czech Republic.

* Economic and Financial Studies Division, European Investment Bank (EIB).
} 


\section{Introduction}

The composition of public spending has been changing in Europe and in OECD countries over the past decades, as the share of public investment has declined while that of other spending categories has increased. As discussed in detail in Section 2, a number of explanations have been offered in earlier literature to account for this stylised fact. The longer-term decline in the share of public investment has been attributed to structural fiscal consolidation efforts, in part linked to the establishment of fiscal rules in the Maastricht treaty and the Stability and Growth Pact. Shorter-term changes in the relative shares have, in turn, been explained by the different cyclical characteristics of public investment and other expenditures, with cyclical downturns generally associated with a decline in the relative share of investment and cyclical upturns with an increase in it.

While there is, then, clearly a link between different types of changes in the fiscal stance and the composition of public spending, our understanding of that link remains incomplete. To the best of our knowledge, no empirical work has been undertaken to examine systematically the link between structural versus cyclical changes in the fiscal stance and the composition of public spending.

While we seek to fill that gap in this paper, we also wish to take the opportunity to address two additional and related questions. First, are there asymmetries between episodes of fiscal consolidation and relaxation as regards their impact on the composition of public expenditure? Some earlier work reviewed in this paper suggests that there might be; however, there has been no formal empirical investigation into this question. Second, how has the decline in the relative share of public investment affected its composition? In other words, have some components of public investment reacted more strongly to structural and cyclical changes in the fiscal stance than others?

Before proceeding, it is important to clarify two issues related to the terminology used in the remainder of the paper. First, the terms "public investment (spending)" and "government investment (spending)" will be used interchangeably, as is customary in related literature. However, as pointed out by Gonzalez Alegre et al. (2008), government investment comprises gross fixed asset formation by the general government, while public investment also includes investment in government-owned corporations, such as many utilities. Thus, although we succumb to custom and 
frequently refer to public investment (spending) below, our sole focus is on government investment (spending).

Second, as will become clear in next section, earlier studies have examined public expenditure composition in a number of different ways, relating the evolution of public investment to other spending categories such as public consumption expenditure, primary spending, current expenditure, or even total outlays. Our focus will be on the relationship between investment and consumption spending, both because that is the economically most relevant comparison and because consumption is most similar to investment as a policy maker's decision variable; thus, by focusing on consumption rather than, e.g., current spending we reduce unwelcome noise due to inherent differences between the components constituting our dependent variable.

These caveats duly noted, we proceed to a review of earlier related literature (section 2). Section 3 presents the empirical analysis, section 4 interprets the results and section 5 concludes.

\section{Related literature}

It is, indeed, a well-established stylised fact that the composition of public spending has been changing in the past two to three decades, with the relative weight of public investment declining. Straub and Tchakarov (2007) document a downtrend in the ratio of public investment to public consumption spending in $12 \mathrm{EU}$ countries since the 1970 s, owing both to a decline in public investment (relative to GDP) and an increase in consumption spending (also relative to GDP). Oxley and Martin (1991) confirm the same for OECD countries between the early 1970s and the early 1990s.

The observation that public investment has been declining in relative terms is robust to the choice of denominator. Thus, de Haan et al. (1996) and Gali and Perotti (2003) consider public investment in relation to total public expenditure in OECD countries, confirming the relative decline of public investment. Balassone and Franco (2000) establish the decline of public investment in relation to primary (non-interest) outlays in EU countries during the 1990s.

There are three different types of explanations to the observed change in the composition of public spending. First, public investment is perceived an easier target politically for cut-backs during times of fiscal stringency or, put differently, during 
episodes of tightening in structural fiscal balances. To quote Oxley and Martin (1991, p. 161);

Most countries have offset such increases [in interest payments, social security transfers and public consumption] by winding back public investment, reflecting the political reality that it is easier to cut-back or postpone investment spending than it is to cut current expenditures.

De Haan et al. (1996) draw the same conclusion based on an empirical study of 22 OECD countries during the period 1980-1992. They examine the impact of both political and economic factors of the ratio of public investment to total outlays finding, notably, that a tightening of the cyclically adjusted fiscal deficit has a significant negative impact on that ratio. They comment on this result by suggesting that investment is “... politically an easier target for cuts than other spending categories" (p. 71).

A second explanation to the relative decline in public investment concerns the role of fiscal rules, notably the Maastricht Treaty and the Stability and Growth Pact (SGP) in the EU. Blanchard and Giavazzi (2004) suggest that the Pact contains a "serious error" in the way public investment is accounted for, depressing it unduly. Balassone and Franco (2000) argue along similar lines, observing that the ratio of public investment to primary outlays declined in the EU during the 1990s, most notably during episodes of "lasting and significant deficit reduction." Gali and Perotti (2003) differ, pointing out that the relative decline of public investment started well before the Maastrict Treaty and the SGP.

Instead, Gali and Perotti (2003) emphasise the pro-cyclicality of public investment, which constitutes the third and final explanation of changes in the composition of public spending. While cyclical ups and downs cannot account for any long-run trends in the relative shares of public spending categories, they can, in principle, explain some of the observed shifts, especially in studies covering short (less than a full cycle) sample periods. Indeed, Lane (2003) studies the cyclicality of spending categories and their determinants based on a sample of 22 OECD countries during 1960-98 and finds that public investment is the most pro-cyclical spending category in the vast majority of old EU member states, with the notable exception of the UK. He also finds that current spending is counter-cyclical in most EU countries, which implies that the ratio of public investment to current spending tends to increase in cyclical upturns and decrease in downturns. 
In sum, earlier related literature has established the relative decline of public investment as a stylised fact, be the denominator public consumption spending, primary expenditure, current spending, or total outlays. Explanations to this change in the composition of public spending have featured the relative political ease of cutting back investment in times of structural fiscal consolidations; the role played by fiscal rules especially in Europe; and the cyclical behaviour of different spending categories.

However, what remains missing is the "big picture" of how different types of changes in the fiscal stance affect public expenditure composition. Earlier studies suggest that structural changes, fiscal rules, and cyclical swings all may play a role, but they do not offer a formal encompassing test of the size and magnitude of the various factors. In addition, they do not address possible asymmetries between fiscal ups and downs in terms of their impact on expenditure composition, nor do they consider which components of public investment have been most affected.

\section{Empirical analysis}

\subsection{Model and estimation methodology}

The stylized facts, established in the earlier literature, of how the composition of public spending has evolved suggest that the relationship between public investment and consumption expenditure has been characterised by a steady change. While the available data do not allow us to analyse its long-term determinants, we can make use of the observation that the ratio of public investment to consumption expenditure has been declining steadily — that is, the ratio has shown some persistence over time ${ }^{1}$ and specify the dynamic model in reduced form as follows:

$$
\begin{aligned}
\left(\frac{I}{C}\right)_{i t} & =\alpha\left(\frac{I}{C}\right)_{i t-1}+\sum_{j=0}^{m}\left(\beta_{j} \Delta N L C C_{i t-j}+\varphi_{j} C U_{i t-j}\right)+\sum_{k=0}^{n}\left(\beta_{k} \Delta N L C A_{i t-k}+\varphi_{k} D T_{i t-k}\right) \\
& +\sum_{l=0}^{p} \beta_{l} X_{l}+\gamma_{i}+u_{i t}
\end{aligned}
$$

where $u_{i t} \sim$ i.i.d $\left(0, \sigma^{2}\right)$, with subscript $i$ referring to observations in the cross-section dimension (individual countries) and $t$ to observations in the time dimension.

\footnotetext{
${ }^{1}$ The first-order autocorrelation of that ratio in our sample, described in detail in section 3.2 , is as high as 0.874 .
} 
The dependent variable is the ratio of public investment to public consumption spending. We consider both aggregate public investment and different types of public investment in the numerator, as explained below in detail.

Our variables of interest are collected in the second and third terms of (1). The first term on the right-hand side of (1) contains the lagged dependent variable. The second term captures the impact of cyclical changes in the fiscal balance: NLCC denotes the cyclical component of net lending by the general government, so $\triangle \mathrm{NLCC}$ measures cyclical tightening $(\triangle \mathrm{NLCC}>0)$ or loosening $(\triangle \mathrm{NLCC}<0)$ of the fiscal stance. $\mathrm{CU}$ is a dummy variable assuming the value 1 whenever there is cyclical tightening $(\triangle \mathrm{NLCC}>0)$, so it captures any asymmetry between cyclical tightening and loosening that there may be. We consider both the contemporaneous and lagged impact of cyclical changes in the fiscal stance; hence the inclusion of lags (m).

Similarly, $\triangle$ NLCA denotes cyclically adjusted changes in the fiscal stance. More specifically, we are interested in structural changes in net lending, not in other non-cyclical changes such as one-off or random ups and downs. DT is a dummy capturing any asymmetries between structural tightenings and loosenings.

The fourth term on the right-hand side contains a number (p) of control variables $\mathrm{X}$. Their role is simply to render the model empirically well-specified, and we do not seek to give them any economic interpretation. The selection of controls is based on earlier empirical literature summarised in section 2, and we pay special attention to testing the robustness of our results with respect to them (section 3.4).

The estimation of (1) will have to account for the correlation between the regressors (lagged dependent) and the composite error term $\left(\gamma_{i}+u_{i t}\right)$ where $\gamma_{i}$ denotes country-specific random effects, which renders least squares estimators inconsistent even asymptotically. To circumvent this problem we employ the General Method of Moments (GMM) estimation (Arellano and Bond, 1991). ${ }^{2}$ To that end, we need to specify a set of moment conditions using instruments that are orthogonal to the error term. Assuming that the error term is not serially correlated and that the explanatory variables are weakly exogenous, higher-order lags of the dependent variable constitute valid instruments. (Higher-order) lags of other, possibly endogenous, explanatory variables can also be used as instruments under the same assumptions.

\footnotetext{
${ }^{2}$ Note that the estimation is done in first differences, eliminating the constant term as well as any fixed effects from (1).
} 
While identification requires the number of instruments to equal the number of explanatory variables, overidentification is in practice necessary, as it both allows the testing of the moment conditions and improves efficiency. There is, however, a possible trade-off between bias and efficiency when the number of instruments (moment conditions) is increased with small samples like ours (see, e.g. Roodman, 2007). We employ the Sargan overidentification test, together with a consideration of the robustness of coefficient estimates to different instrument sets, as a criterion to manage this trade-off.

\subsection{Data}

The dataset consists of a panel of 10 EU member states, ${ }^{3}$ with annual data for the period 1990-2006. Due to the fact that our panel is unbalanced, the total number of observations is 125 .

The ratio of public investment to public consumption expenditure is depicted in Figure 1. That ratio is, on average, about 0.1 , which seems high at the outset, given that total government expenditure in our sample is roughly 50 percent of GDP while investment only amounts to some 2.5 percent of GDP. While we consider government investment as is customary (gross fixed capital formation of the general government), our focus on government consumption means that some categories of current spending, such as interest payments and some subsidies and transfers, are excluded from our denominator.

More specifically, and following Straub and Tchakarov (2007), we employ the variable "final consumption expenditure of the general government," as defined in the UN System of National Accounts, to account for governments' true consumption spending. It comprises non-market output and in-kind social transfers related to expenditure on products supplied to households via market producers. Following that definition, final consumption expenditure amounts on average to 25 percent of GDP in our sample.

\footnotetext{
${ }^{3}$ Austria, Belgium, Denmark, Finland, France, Germany, Italy, the Netherlands, Sweden, and the UK.
} 
Figure 1. Dependent variable

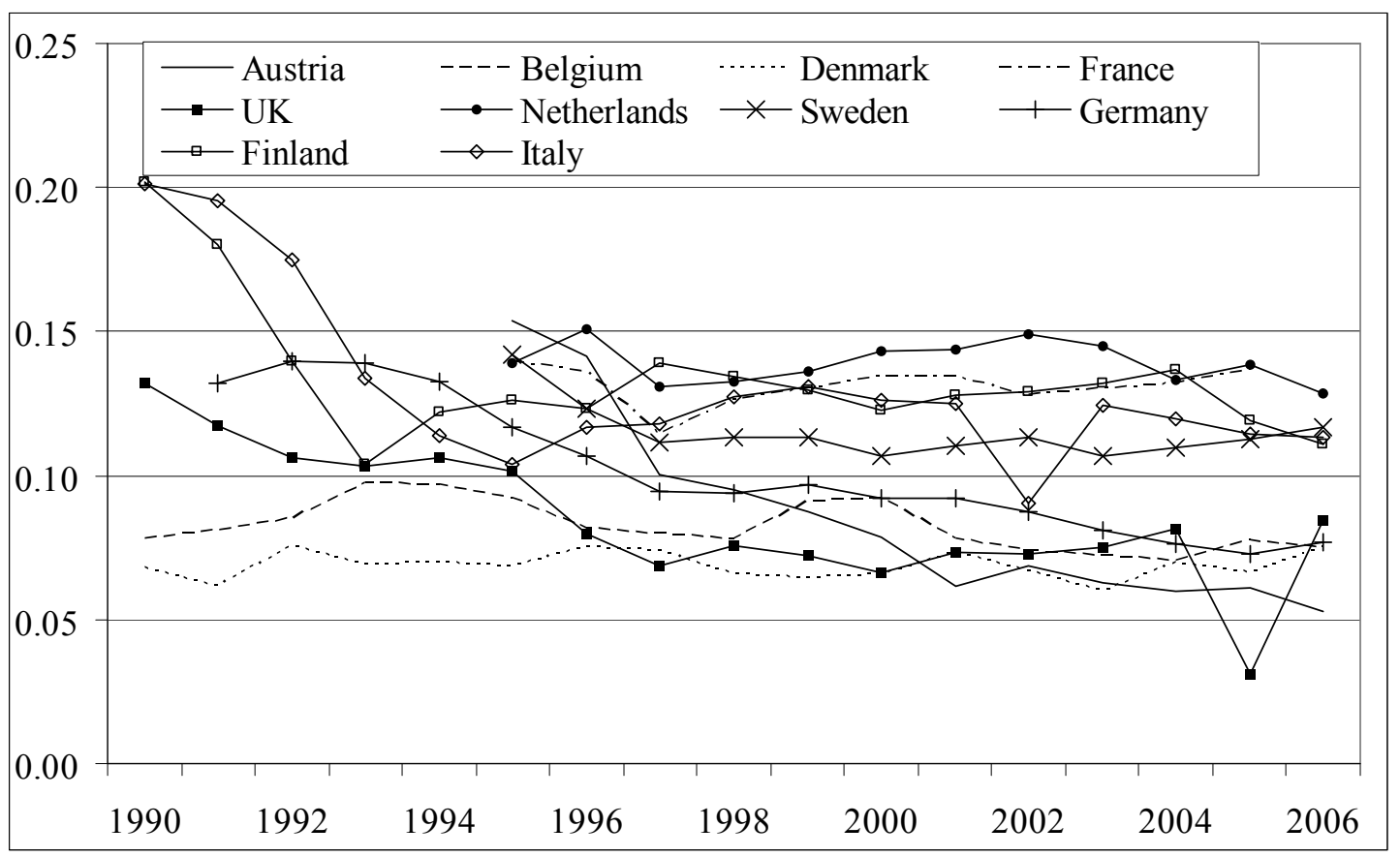

Source: Eurostat, authors' calculations.

When considering different types of government investment in the numerator of the dependent variable, we employ the breakdown introduced in Kappeler and Välilä (2008) into investment in infrastructure, schools and hospitals, public goods, and redistribution. All data on government investment are obtained from Eurostat, while the data on government consumption originates from the OECD.

Turning then to our variables of interest, we use data on the cyclical and discretionary components of net lending as provided by the OECD, with some modification. The methodology for calculating them is explained in Girouard and André (2005). In brief, the cyclically adjusted component (NLCA) is obtained by estimating and removing the cyclical components of government revenues and expenditures. This implies that the cyclically adjusted component contains not only the structural budget balance-which is of key interest to us - but that it also contains other non-cyclical components, including one-off and random changes in government revenues and expenditures. ${ }^{4}$ As a consequence, NLCA displays high volatility, in many cases jumping back and forth between positive and negative values year after year. To mitigate this problem and to obtain a better approximation of the structural

\footnotetext{
${ }^{4}$ Gali and Perotti (2003) refer to the "systematic or endogenous" component of the cyclically adjusted balance and the "non-systematic or exogenous" component without, however, distinguishing between them in the empirical analysis.
} 
budget balance, we smooth the reported NLCA series using the Hodric-Prescott filter $(\lambda=100)$. Both NLCC and NLCA are measured relative to potential GDP.

Finally, the selection of control variables is based on earlier literature (see section 2), complemented with other plausible variables (see section 3.4 on robustness testing). In the end, the set of significant controls include log real GDP per capita (source OECD); public debt relative to GDP (source Ameco); external trade balance relative to GDP (source OECD); the long-term interest rate on government bonds (source OECD); and a dummy variable indicating EMU participation.

Table 1 reports descriptive statistics of the variables employed in the estimation. Panel unit root test results are reported in Annex 1, including both the Levin, Lin and Chu test assuming homogeneity in the individual unit root processes, and the Im, Pesaran and Shin test allowing for individual heterogeneity in the unit root processes. Both tests confirm that all variables are difference stationary. Annex 2 reports correlation coefficients between right-hand side variables. They are appropriately low, with the obvious exception of correlations between cyclical and structural changes in net lending and the corresponding dummies for cyclical and structural tightening. To ensure that the results are robust to these high correlations, we estimate specifications both with and without the dummies.

\subsection{Results}

In this section we report the estimation results for the preferred specification of the model (1). The robustness of the results to different variables treated as endogenous in the estimation; to different sets of control variables; and to a different number of instruments is discussed in section 3.4. Also, only the statistically significant coefficient estimates for different lags of our variables of interest are reported. The interpretation of the results from an economic perspective is done in section 4 . 
Table 1. Descriptive statistics of the data

\begin{tabular}{l|rrrrr}
\hline \hline & $\mathrm{N}$ & mean & sd & $\min$ & $\max$ \\
\hline IC & 148 & 0.106 & 0.032 & 0.031 & 0.202 \\
IC_g1 & 148 & 0.035 & 0.016 & 0.010 & 0.077 \\
IC_g2 & 148 & 0.023 & 0.009 & 0.008 & 0.062 \\
IC_g3 & 148 & 0.027 & 0.011 & -0.034 & 0.061 \\
IC_g4 & 148 & 0.020 & 0.011 & -0.010 & 0.056 \\
NLCC & 148 & -0.232 & 1.112 & -5.278 & 3.245 \\
$\Delta$ NLCC & 145 & -0.013 & 0.853 & -3.428 & 3.380 \\
NLCA & 148 & -1.801 & 2.712 & -12.163 & 6.268 \\
$\Delta$ NLCA & 145 & 0.242 & 0.649 & -2.873 & 4.721 \\
CU & 145 & 0.538 & 0.500 & 0.000 & 1.000 \\
DT & 145 & 0.848 & 0.360 & 0.000 & 1.000 \\
log(GDP) & 148 & 8.569 & 3.151 & 4.254 & 12.587 \\
DebtGDP & 148 & 0.678 & 0.271 & 0.140 & 1.340 \\
IR & 148 & 6.084 & 2.383 & 3.351 & 13.536 \\
ExpImp & 148 & 0.030 & 0.033 & -0.032 & 0.115 \\
EMU & 148 & 0.615 & 0.488 & 0.000 & 1.000 \\
\hline
\end{tabular}

Note: IC is the ratio of public investment to public consumption expenditure, the variables IC gi, $i=1, \ldots, 4$ correspond to the components of public investment, with $\mathrm{i}=1$ being infrastructure; $\mathrm{i}=2$ hospitals and schools; $\mathrm{i}=3$ public goods (including defence, order and safety, environment); and $\mathrm{i}=4$ redistribution (including recreation and social housing). NLCC is a cyclical component of net lending, NLCA is cyclically adjusted net lending, CU is the dummy for cyclical tightening, and DT is the dummy for structural tightening. DebtGDP is the public debt ratio (to GDP), IR denotes the long-term interest rate on government bonds, ExpImp is the trade balance (relative to GDP), and EMU is the EMU dummy.

Table 2 shows the estimation results with the ratio of aggregate public investment to consumption expenditure in value terms as a dependent variable. In the preferred specification the variable GDP is considered endogenous; the only control variables are trade openness (as in Lane, 2003); public debt to GDP (as in Kappeler and Välilä, 2008); and the number of lags of the dependent and GDP used as instruments is 5. Specification A excludes the dummies CU and DT, seeking to capture any asymmetries between fiscal tightening and loosening. Specification B only considers cyclical fiscal changes, while specification $\mathrm{C}$ only considers structural changes. Specification D includes all variables of interest. However, it is important to acknowledge that some of them are highly correlated with one another. 
Table 2. Estimation results with the ratio of public investment to consumption expenditure (value) as dependent variable.

\begin{tabular}{|c|c|c|c|c|}
\hline & $\begin{array}{c}\text { A } \\
\text { coef/p-value }\end{array}$ & $\begin{array}{c}\text { B } \\
\text { coef/p-value } \\
\end{array}$ & $\begin{array}{c}\text { C } \\
\text { coef/p-value }\end{array}$ & $\begin{array}{c}\mathrm{D} \\
\text { coef/p-value }\end{array}$ \\
\hline \multirow[t]{2}{*}{$\mathrm{IC}_{\mathrm{t}-1}$} & 0.4005 & 0.4240 & 0.4037 & 0.3986 \\
\hline & $(0.0000)$ & $(0.0000)$ & $(0.0000)$ & $(0.0000)$ \\
\hline \multirow[t]{2}{*}{$\log (G D P)_{t}($ endog. $)$} & 0.0915 & 0.1369 & 0.1161 & 0.1311 \\
\hline & (0.2829) & (0.1074) & (0.1794) & $(0.1265)$ \\
\hline \multirow[t]{2}{*}{$\log (G D P)_{t-1}($ endog.) } & -0.1479 & -0.1902 & -0.1696 & -0.1939 \\
\hline & $(0.1006)$ & $(0.0348)$ & $(0.0641)$ & $(0.0325)$ \\
\hline \multirow[t]{2}{*}{$\Delta \mathrm{NLCC}_{\mathrm{t}-1}$} & 0.0015 & 0.0037 & & 0.0033 \\
\hline & $(0.1726)$ & $(0.0084)$ & & (0.0219) \\
\hline \multirow[t]{2}{*}{$\Delta \mathrm{NLCA}_{\mathrm{t}-1}$} & 0.0026 & & 0.0042 & 0.0034 \\
\hline & $(0.0760)$ & & $(0.0123)$ & $(0.0464)$ \\
\hline \multirow[t]{2}{*}{$\mathrm{CU}_{\mathrm{t}-1}$} & & -0.0044 & & -0.0045 \\
\hline & & $(0.0807)$ & & $(0.0755)$ \\
\hline \multirow[t]{2}{*}{$D T_{t-1}$} & & & -0.0044 & -0.0031 \\
\hline & & & (0.2399) & $(0.4147)$ \\
\hline \multirow[t]{2}{*}{ DebtGDP $_{t-1}$} & -0.0395 & -0.0361 & -0.0357 & -0.0442 \\
\hline & (0.0209) & $(0.0365)$ & $(0.0324)$ & (0.0114) \\
\hline \multirow[t]{2}{*}{ Explmp $_{t}$} & -0.1120 & -0.1051 & -0.1158 & -0.1208 \\
\hline & $(0.0475)$ & $(0.0549)$ & $(0.0374)$ & $(0.0284)$ \\
\hline Number of observations & 125 & 125 & 125 & 125 \\
\hline Sargan test ( $p$-value) & 0.6341 & 0.5671 & 0.7107 & 0.7113 \\
\hline AR1 (p-value) & 0.0000 & 0.0000 & 0.0000 & 0.0000 \\
\hline AR2 (p-value) & 0.6877 & 0.7822 & 0.6188 & 0.6928 \\
\hline lags & 5 & 5 & 5 & 5 \\
\hline
\end{tabular}

Note: IC is the ratio of public investment to public consumption expenditure, NLCC is the cyclical component of net lending, NLCA is cyclically adjusted net lending, $\mathrm{CU}$ is the dummy for cyclical tightening, DT is the dummy for structural tightening, DebtGDP is the public debt ratio (to GDP), and ExpImp is the trade balance (relative to GDP).

Consider first the impact of cyclical and structural changes in net lending on the composition of public spending. As shown in Table 2, only the first lags of these variables are statistically significant. Both have positive coefficients, suggesting that cyclical and structural fiscal tightening (increase in net lending) is associated with an increase in public investment relative to consumption expenditure in the following year. Conversely, cyclical and structural loosening (decrease in net lending) is associated with a decrease in the relative share of public investment the year after.

The coefficient estimates are robust in terms of significance and magnitude; only in specification $\mathrm{A}$ is the coefficient for cyclical changes in net lending insignificant. In all other specifications a one-percentage point of GDP increase (decrease) in net lending leads roughly to a 0.3 percentage point increase (decrease) in the ratio of public investment to consumption expenditure. Recalling that the average 
ratio in our sample is about 10 percent, a one-percentage point of GDP tightening would then increase the relative share of investment by some 3 percent.

The structural tightening/loosening dummy DT is insignificant, so there are no asymmetries between structural tightening and loosening of the fiscal stance. However, the cyclical tightening/loosening dummy CU is significant (albeit only at the 10 percent level) and negative, which implies that the increase in the investmentto-consumption ratio following a cyclical tightening is smaller than the decrease in that ratio following a cyclical loosening. In other words, the relative gain in investment following a cyclical tightening is smaller than the relative gain in consumption following a loosening.

Moving then to consider how the individual components of public investment move relative to public consumption expenditure, Table 3 reports the estimation results with each of the four components as the numerator of the dependent variable in turn. We now consider public debt (relative to GDP) as endogenous, and we also add the EMU dummy and the long-term government interest rate as control variables in some cases. The preferred number of lags used as instruments varies between 2 and 5 .

The relative share of infrastructure investment behaves as aggregate public investment, with cyclical and structural tightening (loosening) increasing (decreasing) it relative to consumption expenditure, with no observable asymmetries present. That infrastructure investment and aggregate public investment behave similarly is no surprise given that infrastructure is the single biggest component in aggregate investment, accounting for about one-third of it (Kappeler and Välilä, 2008).

Investment in hospitals and schools increases (decreases) relative to consumption expenditure following a structural tightening (loosening) of the fiscal stance, while it does not react significantly to cyclical changes. In addition, the reaction to structural changes is symmetric; the gain in investment in hospitals and schools following a tightening is similar to the gain in consumption following a loosening.

While investment in public goods does not seem to react systematically to either cyclical or structural changes in the fiscal stance, there is some evidence that it increases contemporaneously relative to consumption expenditure following a cyclical tightening (the coefficient for the CU dummy is significant and positive). 
Finally, redistribution investment gains relative to consumption expenditure following cyclical tightening and loses following a loosening, with no significant asymmetry observable.

Table 3. Estimation results with the ratio of components of public investment to consumption expenditure (value) as dependent variable.

\begin{tabular}{|c|c|c|c|c|}
\hline & $\begin{array}{l}\text { Infrastructure } \\
\text { coef/p-value }\end{array}$ & $\begin{array}{c}\text { Hospitals \& } \\
\text { Schools } \\
\text { coef/p-value } \\
\end{array}$ & $\begin{array}{l}\text { Public Goods } \\
\text { coef/p-value }\end{array}$ & $\begin{array}{l}\text { Redistribution } \\
\text { coef/p-value }\end{array}$ \\
\hline IC_g $1_{t-1}$ & $\begin{array}{r}\mathbf{0 . 4 3 1 0} \\
(0.0000)\end{array}$ & & & \\
\hline IC_g2 $2_{t-1}$ & & $\begin{array}{r}\mathbf{0 . 3 2 8 3} \\
(0.0000)\end{array}$ & & \\
\hline IC_g3 $3_{t-1}$ & & & $\begin{array}{r}0.1725 \\
(0.0514)\end{array}$ & \\
\hline IC_g $4_{t-1}$ & & & & $\begin{array}{r}\mathbf{0 . 1 6 2 2} \\
(0.0866)\end{array}$ \\
\hline DebtGDP $_{t}$ (endog.) & $\begin{array}{c}-0.0183 \\
(0.0873)\end{array}$ & $\begin{array}{r}-\mathbf{0 . 0 1 6 3} \\
(0.0379)\end{array}$ & $\begin{array}{c}-0.0458 \\
(0.0337)\end{array}$ & $\begin{array}{r}0.0025 \\
(0.8856)\end{array}$ \\
\hline DebtGDP $_{\mathrm{t}-1}$ (endog.) & $\begin{array}{r}-0.0007 \\
(0.9419)\end{array}$ & $\begin{array}{r}0.0098 \\
(0.1669)\end{array}$ & $\begin{array}{r}0.0094 \\
(0.6378)\end{array}$ & $\begin{array}{r}-0.0083 \\
(0.5626)\end{array}$ \\
\hline$\Delta \mathrm{NLCC}_{\mathrm{t}-1}$ & $\begin{array}{r}\mathbf{0 . 0 0 1 0} \\
(0.0235)\end{array}$ & $\begin{array}{r}0.0003 \\
(0.2832)\end{array}$ & & $\begin{array}{r}\mathbf{0 . 0 0 0 8} \\
(0.0914)\end{array}$ \\
\hline$\Delta \mathrm{NLCA}_{\mathrm{t}-1}$ & $\begin{array}{r}0.0005 \\
(0.3045)\end{array}$ & $\begin{array}{r}\mathbf{0 . 0 0 0 7} \\
(0.0331)\end{array}$ & & \\
\hline $\mathrm{CU}_{\mathrm{t}}$ & & & $\begin{array}{r}\mathbf{0 . 0 0 2 1} \\
(0.0976)\end{array}$ & \\
\hline $\mathrm{CU}_{\mathrm{t}-1}$ & $\begin{array}{r}-0.0010 \\
(0.1763)\end{array}$ & & & \\
\hline $\log (G D P)_{t}$ & $\begin{array}{r}-0.0234 \\
(0.0020)\end{array}$ & $\begin{array}{r}-0.0163 \\
(0.0040)\end{array}$ & $\begin{array}{c}-0.0742 \\
(0.0000)\end{array}$ & $\begin{array}{r}-0.0179 \\
(0.0664)\end{array}$ \\
\hline Explmp $_{t}$ & $\begin{array}{r}-0.0537 \\
(0.0110)\end{array}$ & $\begin{array}{r}-0.0475 \\
(0.0119)\end{array}$ & & \\
\hline $\mathrm{EMU}_{\mathrm{t}}$ & & $\begin{array}{r}-0.0017 \\
(0.2189)\end{array}$ & & \\
\hline $\mathrm{IR}_{\mathrm{t}}$ & & $\begin{array}{r}-0.0004 \\
(0.0584) \\
\end{array}$ & $\begin{array}{r}-0.0002 \\
(0.6858)\end{array}$ & \\
\hline Number of observations & 125 & 125 & 128 & 125 \\
\hline Sargan test ( $p$-value) & 0.1513 & 0.2018 & 0.6101 & 0.8094 \\
\hline AR1 (p-value) & 0.0005 & 0.0002 & 0.0000 & 0.0000 \\
\hline $\begin{array}{l}\text { AR2 (p-value) } \\
\text { lags }\end{array}$ & $\begin{array}{l}0.2735 \\
2\end{array}$ & $\begin{array}{l}0.9412 \\
3\end{array}$ & $\begin{array}{l}0.5605 \\
5\end{array}$ & $2^{0.9748}$ \\
\hline
\end{tabular}

Note: The variables IC $g i, i=1, \ldots, 4$ correspond to the components of public investment, with $i=1$ being infrastructure; $i=2$ hospitals and schools; $i=3$ public goods (including defence, order and safety, environment); and $\mathrm{i}=4$ redistribution (including recreation and social housing). NLCC is cyclical component of net lending, NLCA is cyclically adjusted net lending, CU is the dummy for cyclical tightening, DebtGDP is the public debt ratio (to GDP), IR denotes the long-term interest rate on government bonds, ExpImp is the trade balance (relative to GDP), and EMU is the EMU dummy. 
In terms of magnitudes of the estimated effects, infrastructure investment reacts more strongly in absolute terms to cyclical swings in the fiscal stance than investment in either hospitals and schools or redistribution.

In sum, we find no evidence that fiscal tightening (decrease in net lending) of any kind would reduce the share of public investment relative to consumption expenditure. On the contrary, cyclical tightening boosts the relative share of investment in infrastructure; hospitals and schools; and redistribution, while structural tightening boosts the relative share of investment in hospitals and schools. However, we have found some evidence that the gain in investment as a result of a fiscal tightening is smaller than the gain in consumption following a fiscal loosening.

\subsection{Robustness testing}

The results reported above are based on a reduced-form model specification that could, in principle, exert a significant impact on the estimation results. To assure the robustness of the results to such influences, we consider in this section a number of alternative specifications and modelling choices.

To start with the specification of the dependent variable, we note that the numerator and the denominator were measured above in value terms; that is, we used the original observations, rather than any transformation of them. As both variables are also available in volume (real) terms, we estimate (1) using them. The results are reported in Table 4. To render the estimated model well-specified, we treat debt (to GDP) as endogenous and consider 5 lags as instruments. We also include the longterm government interest rate as a control variable, given that there was some evidence of its significance (see Table 3 ).

Cyclical changes in the fiscal stance have now turned out to be insignificant, but there is still some evidence of a decrease in the ratio of investment to consumption expenditure following a cyclical tightening. However, the coefficient for $\mathrm{CU}_{\mathrm{t}-1}$ (dummy for cyclical tightening) is only significant at the 10 percent level, so that evidence is weak.

Structural changes in the fiscal stance remain significant, with a tightening (loosening) associated with an increase (decrease) in the ratio of investment to consumption spending. Moreover, the coefficient for $\mathrm{DT}_{\mathrm{t}-1}$ (dummy for structural tightening) is now significant (it was negative but insignificant in Table 2), suggesting 
that the response of the ratio to a fiscal tightening is smaller than it is to a fiscal loosening.

Table 4. Estimation results with the ratio of public investment to consumption expenditure (volume) as dependent variable.

\begin{tabular}{|c|c|c|c|c|}
\hline & $\begin{array}{c}\mathrm{A} \\
\text { coef/p-value } \\
\end{array}$ & $\begin{array}{c}\text { B } \\
\text { coef/p-value } \\
\end{array}$ & $\begin{array}{c}\mathrm{C} \\
\text { coef/p-value }\end{array}$ & $\begin{array}{c}\mathrm{D} \\
\text { coef/p-value } \\
\end{array}$ \\
\hline \multirow{2}{*}{$\mathrm{IC}_{\mathrm{t}-1}$} & 0.6066 & 0.6139 & 0.5658 & 0.5722 \\
\hline & $(0.0000)$ & $(0.0000)$ & $(0.0000)$ & $(0.0000)$ \\
\hline \multirow[t]{2}{*}{ DebtGDP $_{\mathrm{t}}$ (endog.) } & 0.0131 & 0.0022 & 0.0176 & 0.0075 \\
\hline & $(0.7068)$ & (0.9478) & (0.5973) & (0.8271) \\
\hline \multirow[t]{2}{*}{ DebtGDP $_{\mathrm{t}-1}$ (endog.) } & -0.0203 & -0.0038 & -0.0202 & -0.0081 \\
\hline & $(0.5357)$ & $(0.9054)$ & $(0.4989)$ & $(0.8058)$ \\
\hline \multirow[t]{2}{*}{$\Delta \mathrm{NLCC}_{\mathrm{t}-1}$} & -0.0004 & 0.0014 & & 0.0010 \\
\hline & $(0.7303)$ & $(0.3448)$ & & $(0.5067)$ \\
\hline \multirow[t]{2}{*}{$\Delta \mathrm{NLCA}_{\mathrm{t}-1}$} & 0.0013 & & 0.0042 & 0.0042 \\
\hline & $(0.4582)$ & & (0.0304) & $(0.0280)$ \\
\hline \multirow[t]{2}{*}{$\mathrm{CU}_{\mathrm{t}-1}$} & & -0.0045 & & -0.0036 \\
\hline & & $(0.0854)$ & & (0.1816) \\
\hline \multirow[t]{2}{*}{$\mathrm{DT}_{\mathrm{t}-1}$} & & & -0.0123 & -0.0113 \\
\hline & & & $(0.0010)$ & (0.0023) \\
\hline \multirow[t]{2}{*}{$\log (G D P)_{t}$} & 0.0023 & 0.0082 & 0.0069 & 0.0113 \\
\hline & (0.9296) & $(0.7557)$ & $(0.7934)$ & $(0.6658)$ \\
\hline \multirow[t]{2}{*}{ Explmp $_{t}$} & -0.1618 & -0.1641 & -0.1554 & -0.1612 \\
\hline & $(0.0177)$ & $(0.0147)$ & $(0.0245)$ & $(0.0125)$ \\
\hline \multirow[t]{2}{*}{$\mathrm{IR}_{\mathrm{t}}$} & -0.0004 & -0.0002 & -0.0007 & -0.0004 \\
\hline & $(0.5968)$ & $(0.8131)$ & $(0.4086)$ & $(0.6217)$ \\
\hline Number of observations & 139 & 139 & 139 & 139 \\
\hline Sargan test ( $p$-value) & 0.7487 & 0.7227 & 0.9143 & 0.9180 \\
\hline AR1 (p-value) & 0.0000 & 0.0000 & 0.0000 & 0.0000 \\
\hline AR2 (p-value) & 0.8513 & 0.8485 & 0.5676 & 0.5702 \\
\hline lags & 5 & 5 & 5 & 5 \\
\hline
\end{tabular}

Note: IC is the ratio of public investment to public consumption expenditure, NLCC is cyclical component of net lending, NLCA is cyclically adjusted net lending, CU is the dummy for cyclical tightening, DT is the dummy for structural tightening, DebtGDP is the public debt ratio (to GDP), IR denotes the long-term interest rate on government bonds, and ExpImp is the trade balance (relative to GDP).

A second robustness test we carried out concerns the set of control variables. As shown in the tables above, only trade openness is systematically significant (as in Lane, 2003); the long-term government interest rate or the EMU dummy are not systematically significant. We also considered a number of other controls that one or the other earlier study has found significant. Additional controls considered but found predominantly insignificant in our case include population, population growth, population density, unemployment rate, foreign direct investment inflows, and various measures of urbanisation. 
We also considered alternative choices of right-hand side variables treated as endogenous, as well as alternative numbers of lags of the dependent and the endogenous variables used as instruments. While we do not consider endogeneity of explanatory variables a major issue (after all, most of them are lagged and hence predetermined), the contemporaneous values of GDP and public debt (to GDP) are candidates for being endogenous. We thus considered both of them jointly and each of them individually as endogenous, and selected the specification suggested best by the Sargan test of overidentifying restrictions. Relatedly, the number of lags included was selected with the trade-off between bias and efficiency in mind: in our case increasing the number of lags led invariably to significant changes in the coefficient estimates, suggesting that bias may be an issue. This being the case, we opted for a small number of lags, subject to them passing the Sargan test.

\section{Economic interpretation of the results}

Our key results can be summarised as follows:

- Structural tightening of the fiscal stance increases public investment relative to consumption expenditure with a lag of one year, while a structural loosening reduces the relative share of investment with a similar lag. There is some evidence that the gain in investment following a tightening is smaller than the gain in consumption expenditure following a loosening. The component of investment contributing most clearly to these patterns include hospitals and schools.

- Cyclical changes in the fiscal stance have a similar impact, although the evidence is less robust to the measurement (values or volumes) of investment and consumption expenditure. The components of investment responsible for the cyclical movements include infrastructure and redistribution (such as social housing).

These results stand in clear contrast to some of those in earlier literature, which concluded that the relative ease in cutting investment in episodes of fiscal stringency and/or because of the fiscal rules embedded in Maastricht Treaty and the Stability and Growth Pact both have exerted downward pressure on the ratio of public investment to consumption expenditure. To repeat, our results suggest that structural fiscal tightening tends to increase, not reduce, public investment relative to consumption 
expenditure. We also find no evidence that EMU's fiscal rules would have exerted any significant impact on the composition of public spending.

However, we do find some support for the findings of Lane (2003), suggesting that the different cyclical patterns of public investment and current spending imply an increase in the ratio between them during cyclical upturns and a decline in downturns. Again, we found a cyclical fiscal tightening (i.e., an upturn in the business cycle) increasing the ratio, while a cyclical loosening (i.e., a cyclical downturn) reduces it.

There are obvious differences between this and earlier studies that render them only incompletely comparable. The samples differ, with ours covering a decade or more of observations than any of the earlier studies. We also limit the analysis to European countries, while most earlier studies consider a more heterogeneous group of OECD countries. The model specification and estimation methodologies differ, too, as we seek to present an encompassing analysis of the impact of both cyclical and structural changes on the composition of public spending, instead of just considering one of these aspects in isolation.

In any case, our results underline how incompletely the relationship between changes in the fiscal stance and the composition of public spending is understood. The results related to cyclical changes in the fiscal stance and in the composition of public expenditure seem least controversial, but we can only speculate about why cyclical upturns tend to increase the relative share of public investment in infrastructure and redistribution at the expense of consumption expenditure. Automatic stabilisers are likely to play a role, reducing social transfers and public consumption. The cyclicality of the components of public investment and its determinants have not been addressed in earlier literature, so we can only consider the observed cyclicality of infrastructure and redistribution investment as a stylised fact waiting to be explained in future research.

An arguably more intriguing finding is the observed behaviour of public spending composition following structural changes in the fiscal stance. Especially, why does investment in hospitals and schools gain in relative terms following structural fiscal tightening and loses, again in relative terms, following a structural relaxation? Part of the explanation may again lie in the denominator, with structural changes affecting consumption spending. Indeed, the literature on the success of fiscal consolidations (see European Commission, 2007, for a survey) emphasises the 
importance of current spending cuts for their success. However, our sample includes all types of consolidation (as well as structural relaxation) episodes, and whether successful (however defined) consolidations have a different impact on public spending composition than unsuccessful ones is another topic for future research to tackle.

Many studies have emphasised the importance of political determinants for aggregate public investment, and perhaps the differences between the components of public investment in their reaction to structural (and also cyclical) changes in the fiscal stance are indeed linked to such political factors. There is no obvious economic reason why investment in hospitals and schools should be more responsive to structural fiscal changes (or why investment in infrastructure should be more responsive to cyclical changes). However, a challenge for finding political-economy explanations for the results obtained here is that the direction and pattern of observed changes is so counter-intuitive. After all, what kind of a political objective function could imply support for children (schools) rather than, e.g., poor voters (social housing) at times of fiscal stringency?

\section{Conclusion}

Both cyclically-induced and structural changes in the fiscal stance affect the composition of public spending, with fiscal tightening of both types increasing the relative share of investment and loosening favouring consumption expenditure. There is, however, some asymmetry in that the gain in investment following a tightening tends to be smaller than the gain in consumption expenditure following a loosening. Of the components of public investment, infrastructure and redistribution respond to cyclical changes in the fiscal stance, while investment in hospitals and schools responds most clearly to structural changes.

The results pertaining to the impact of cyclical changes are in line with earlier literature and more intuitive economically. To fully understand the observed results on structural fiscal changes requires further research, possibly including politicaleconomy aspects of public expenditure determination. 


\section{Literature}

Arrelano, M., \& Bond, S. 1991. Some Tests of Specification for Panel Data: Monte Carlo Evidence and an Application to Employment Equations. Review of Economics Studies, 58, 277-297.

Balassone, F., \& Franco, D. 2000. Public Investment, the Stability Pact and the 'Golden Rule.' Fiscal Studies, 21(2), 207-229.

Blanchard, O., \& Giavazzi, F. 2004. Improving the SGP through a Proper Accounting of Public Investment. CEPR Discussion Paper, 4220.

Gali, J., \& Perotti, R. 2003. Fiscal Policy and Monetary Integration in Europe. Economic Policy, October, 533-572.

Girouard, N., \& André, C. 2005. Measuring Cyclically Adjusted Budget Balances for OECD Countries. OECD Economics Department Working Papers, 434.

Gonzalez Alegre, J., Kappeler, A., Kolev, A., \& Välilä, T. 2008. Composition of Government Investment in Europe: Some Forensic Evidence. EIB Papers, 12(1), 23-54.

De Haan, J., Sturm, J. E., \& Sikken, B. 1996. Government Capital Formation: Explaining the Decline. Weltwirtschaftliches Archiv, 132(1), 55-74.

European Commission, 2007. European Economy No 3. Public Finances in EMU 2007.

Kappeler, A., \& Välilä, T. 2008. Fiscal Federalism and the Composition of Public Investment in Europe. European Journal of Political Economy, 24(3), 562570.

Lane, P. R. 2003. The Cyclical Behaviour of Fiscal Policy: Evidence from the OECD. Journal of Public Economics, 87, 2661-2675. 
Oxley, H., \& Martin, J. P. 1991. Controlling Government Spending and Deficits: Trends in the 1980s and Prospects for the 1990s. OECD Economic Studies, 17, 145-189.

Roodman, D. 2007. A Short Note on the Theme of Too Many Instruments. Center for Global Development Working Paper, 125, Center for Global Development, Washington.

Straub, R., \& Tchakarov, I. 2007. Assessing the Impact of a Change in the Composition of Public Spending: A DSGE Approach. IMF Working Paper, $07 / 168$. 
Annex 1. Unit root test results

\begin{tabular}{|c|c|c|c|c|c|c|}
\hline & \multirow[b]{2}{*}{ stationarity } & \multirow[b]{2}{*}{$\mathrm{N}$} & \multicolumn{2}{|c|}{ Levin, Lin, Chu } & \multicolumn{2}{|c|}{ Im, Pesaran \& Shin } \\
\hline & & & statistics & $p$-value & statistics & $\mathrm{p}$-value \\
\hline \multirow[t]{2}{*}{ IC } & level & 134 & -6.725 & 0.000 & -5.397 & 0.000 \\
\hline & difference & 121 & -8.560 & 0.000 & -6.688 & 0.000 \\
\hline \multirow[t]{2}{*}{ IC_g1 } & level & 133 & -3.240 & 0.001 & -3.171 & 0.001 \\
\hline & difference & 124 & -7.639 & 0.000 & -6.475 & 0.000 \\
\hline \multirow[t]{2}{*}{ IC_g2 } & level & 129 & -5.898 & 0.000 & -4.382 & 0.000 \\
\hline & difference & 122 & -10.714 & 0.000 & -8.034 & 0.000 \\
\hline \multirow[t]{2}{*}{ IC_g3 } & level & 132 & -11.689 & 0.000 & -5.982 & 0.000 \\
\hline & difference & 122 & -10.911 & 0.000 & -8.618 & 0.000 \\
\hline \multirow[t]{2}{*}{ IC_g4 } & level & 136 & -4.169 & 0.000 & -2.746 & 0.003 \\
\hline & difference & 126 & -9.338 & 0.000 & -6.702 & 0.000 \\
\hline \multirow[t]{2}{*}{$\triangle N L C C$} & level & 130 & -5.995 & 0.000 & -5.302 & 0.000 \\
\hline & difference & 121 & -9.312 & 0.000 & -7.235 & 0.000 \\
\hline \multirow{2}{*}{$\triangle \mathrm{NLCA}$} & level & 118 & -6.245 & 0.000 & -11.732 & 0.000 \\
\hline & difference & 114 & -6.999 & 0.000 & -8.273 & 0.000 \\
\hline \multirow[t]{2}{*}{$\log (G D P)$} & level & 133 & -1.786 & 0.037 & 1.981 & 0.976 \\
\hline & difference & 126 & -5.254 & 0.000 & -3.966 & 0.000 \\
\hline \multirow[t]{2}{*}{ DebtGDP } & level & 129 & -0.135 & 0.446 & 0.154 & 0.561 \\
\hline & difference & 124 & -4.180 & 0.000 & -2.705 & 0.003 \\
\hline \multirow[t]{2}{*}{ IR } & level & 135 & -5.096 & 0.000 & -2.064 & 0.020 \\
\hline & difference & 124 & -8.047 & 0.000 & -6.390 & 0.000 \\
\hline \multirow[t]{2}{*}{ Explmp } & level & 135 & 0.470 & 0.681 & 2.939 & 0.998 \\
\hline & difference & 126 & -7.969 & 0.000 & -5.411 & 0.000 \\
\hline
\end{tabular}

Note: Automatic selection of lags by AIC. IC is the ratio of public investment to public consumption expenditure, the variables IC_gi, $i=1, \ldots, 4$ correspond to the components of public investment, with $i=1$ being infrastructure; $i=2$ hospitals and schools; $i=3$ public goods (including defence, order and safety, environment); and $\mathrm{i}=4$ redistribution (including recreation and social housing). NLCC is a cyclical component of net lending, NLCA is cyclically adjusted net lending, DebtGDP is the public debt ratio (to GDP), IR denotes the long-term interest rate on government bonds, and ExpImp is the trade balance (relative to GDP). 
Annex 2. Correlation matrix

\begin{tabular}{|c|c|c|c|c|c|c|c|c|c|c|c|c|}
\hline & 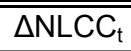 & $\overline{\Delta \mathrm{NLCC}_{\mathrm{t}-1}}$ & 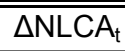 & 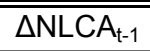 & 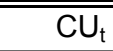 & $\overline{\mathrm{CU}_{\mathrm{t}-1}}$ & 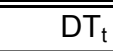 & 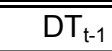 & 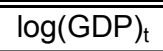 & 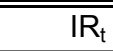 & Explmp $_{t}$ & 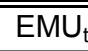 \\
\hline$\overline{\Delta \mathrm{NLCC}_{\mathrm{t}}}$ & 1 & & & & & & & & & & & \\
\hline$\Delta \mathrm{NLCC}_{\mathrm{t}-1}$ & 0.201 & 1 & & & & & & & & & & \\
\hline$\Delta \mathrm{NLCA}_{\mathrm{t}}$ & 0.335 & 0.231 & 1 & & & & & & & & & \\
\hline$\Delta \mathrm{NLCA}_{\mathrm{t}-1}$ & 0.193 & 0.321 & 0.162 & 1 & & & & & & & & \\
\hline $\mathrm{CU}_{\mathrm{t}}$ & 0.695 & 0.193 & 0.246 & 0.086 & 1 & & & & & & & \\
\hline $\mathrm{CU}_{\mathrm{t}-1}$ & 0.328 & 0.696 & 0.184 & 0.238 & 0.282 & 1 & & & & & & \\
\hline $\mathrm{DT}_{\mathrm{t}}$ & 0.220 & 0.179 & 0.515 & 0.208 & 0.225 & 0.105 & 1 & & & & & \\
\hline$D T_{t-1}$ & 0.103 & 0.160 & 0.152 & 0.508 & 0.114 & 0.157 & 0.659 & 1 & & & & \\
\hline $\log (G D P)_{t}$ & 0.094 & 0.099 & 0.032 & 0.025 & 0.052 & 0.050 & 0.284 & 0.264 & 1 & & & \\
\hline $\mathrm{IR}_{\mathrm{t}}$ & -0.167 & -0.107 & -0.021 & -0.058 & -0.081 & -0.002 & -0.121 & -0.174 & -0.195 & 1 & & \\
\hline Explmp $_{t}$ & 0.121 & 0.040 & 0.164 & 0.140 & 0.071 & 0.007 & 0.141 & 0.106 & 0.225 & -0.259 & 1 & \\
\hline $\mathrm{EMU}_{\mathrm{t}}$ & 0.056 & -0.029 & 0.089 & 0.077 & 0.059 & -0.034 & 0.112 & 0.093 & -0.443 & -0.365 & 0.058 & 1 \\
\hline
\end{tabular}

Note: NLCC is a cyclical component of net lending, NLCA is cyclically adjusted net lending, CU is the dummy for cyclical tightening, DT is the dummy for structural tightening, IR denotes the long-term interest rate on government bonds, ExpImp is the trade balance (relative to GDP), and EMU is the EMU dummy. 
Individual researchers, as well as the on-line and printed versions of the CERGE-EI Working Papers (including their dissemination) were supported from the European Structural Fund (within the Operational Programme Prague Adaptability), the budget of the City of Prague, the Czech Republic's state budget and the following institutional grants:

- Center of Advanced Political Economy Research [Centrum pro pokročilá politickoekonomická studia], No. LC542, (2005-2009),

- Economic Aspects of EU and EMU Entry [Ekonomické aspekty vstupu do Evropské unie a Evropské měnové unie], No. AVOZ70850503, (2005-2010);

- Economic Impact of European Integration on the Czech Republic [Ekonomické dopady evropské integrace na ČR], No. MSM0021620846, (2005-2011);

Specific research support and/or other grants the researchers/publications benefited from are acknowledged at the beginning of the Paper.

(c) Juraj Stančík and Timo Välilä, 2009.

All rights reserved. No part of this publication may be reproduced, stored in a retrieval system or transmitted in any form or by any means, electronic, mechanical or photocopying, recording, or otherwise without the prior permission of the publisher.

Published by

Charles University in Prague, Center for Economic Research and Graduate Education (CERGE) and

Economics Institute ASCR, v. v. i. (EI)

CERGE-El, Politických vězňů 7, 11121 Prague 1, tel.: +420 224005 153, Czech Republic.

Printed by CERGE-EI, Prague

Subscription: CERGE-EI homepage: http://www.cerge-ei.cz

Editors: Directors of CERGE and EI

Managing editors: Deputy Directors for Research of CERGE and EI

ISSN 1211-3298

ISBN 978-80-7343-196-9 (Univerzita Karlova. Centrum pro ekonomický výzkum

a doktorské studium)

ISBN 978-80-7344-185-2 (Národohospodářský ústav AV ČR, v. v. i.) 
CERGE-EI

P.O.BOX 882

Politických vězňů 7

11121 Praha 1

Czech Republic http://www.cerge-ei.cz 